\title{
High concentration of levamisole in the diet of Colossoma macropomum (Pisces: Serrasalmidae) is effective for controlling monogenean parasites
}

Alta concentração de levamisol na dieta de Colossoma macropomum (Pisces: Serrasalmidae) é efetiva para controlar parasitos monogenea

Joziele Neves Nogueira ${ }^{1}$; Gracienhe Gomes Santos²; Marcos Tavares-Dias ${ }^{3 *}$ (D)

\author{
${ }^{1}$ Universidade do Estado do Amapá (UEAP), Macapá, AP, Brasil \\ ${ }^{2}$ Programa de Pós-Graduação em Aquicultura, Universidade Federal de Santa Catarina (UFSC), Florianópolis, SC, Brasil \\ ${ }^{3}$ Embrapa Amapá, Macapá, AP, Brasil
}

Received August 27, 2019

October 7, 2019

\begin{abstract}
This study investigated the effects of diets supplemented with levamisole on monogeneans on the gills of Colossoma macropomum. Fish were fed with diets containing levamisole at concentrations of 0, 300, 600, 900 and $1200 \mathrm{mg} \mathrm{kg}^{-1}$ for 24, 96 and $240 \mathrm{~h}$ and the infection by Anacanthorus spatulatus, Notozothecium janauachensis and Mymarothecium boegeri were evaluated. None of the levamisole concentrations caused either mortality or behavioral alterations in fishes during $240 \mathrm{~h}$ of feeding. After $24 \mathrm{~h}$ of feeding with $1200 \mathrm{mg} \mathrm{kg}^{-1}$ of levamisole, the abundance of $N$. janauachensis decreased in comparison with treatments of $0,300,600$ and $900 \mathrm{mg} \mathrm{kg}^{-1}$, as did the abundance of $M$. boegeri after $240 \mathrm{~h}$ of feeding with $1200 \mathrm{mg} \mathrm{kg}^{-1}$ of levamisole. The efficacy of $900 \mathrm{mg} \mathrm{kg}^{-1}$ of levamisole was only $55.7 \%$ after $96 \mathrm{~h}$ of feeding, but it was $84.6 \%$ after $240 \mathrm{~h}$ of feeding with $1200 \mathrm{mg} \mathrm{kg}^{-1}$. Our results show that $1200 \mathrm{mg} \mathrm{kg}^{-1}$ of levamisole for 10 days has good anthelmintic efficacy against monogeneans of $C$. macropomum. Since monogeneans elicit some of the worst problems in C. macropomum, this study has provided evidence of an effective control method that may be used in fish farms.
\end{abstract}

Keywords: Anthelmintic, dietary supplementation, efficacy, parasites.

\section{Resumo}

Este estudo investigou os efeitos de dietas suplementadas com levamisol na infecção por monogeneas nas brânquias de

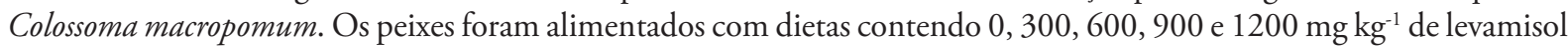
por 24, 96 e 240 h e os níveis de infecção por Anacanthorus spatulatus, Notozothecium janauachensis e Mymarothecium boegeri, foram avaliados. Nenhuma das concentraçôes de levamisol causou mortalidade ou alteraçóes comportamentais nos peixes durante $240 \mathrm{~h}$ de alimentação. Após $24 \mathrm{~h}$ de alimentação com $1.200 \mathrm{mg} \mathrm{kg}^{-1}$ de levamisol, a abundância de $N$. janauachensis diminuiu quando comparada aos tratamentos com 0, 300, 600 e $900 \mathrm{mg} \mathrm{kg}^{-1}$, bem como a abundância de

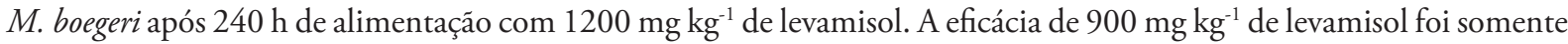
de 55,7\% após 96 h de alimentação, mas foi de 84,6\% após 240 h de alimentação com $1200 \mathrm{mg} \mathrm{kg}^{-1}$. Os resultados mostram que $1200 \mathrm{mg} \mathrm{kg}^{-1}$ de levamisol durante 10 dias, tem uma boa eficácia antihelmíntica contra monogeneas de C. macropomum. Como monogeneas provocam alguns dos piores problemas em C. macropomum, este estudo forneceu evidências de um método de controle eficaz que pode ser usado em pisciculturas.

Palavras-chave: Antihelmíntico, eficácia, parasitos, suplementação dietética.

\section{Introduction}

Monogeneans are a class of parasitic Platyhelminthes that are ubiquitous in aquatic environments and that are harmful for farmed fish (MORALES-SERNA et al., 2018; ALVES et al., 2019). These

*Corresponding author: Marcos Tavares-Dias. Embrapa Amapá, Rodovia Juscelino Kubitschek, Km 5, 2600, CEP 68903-419, Macapá, AP, Brasil. e-mail: marcos.tavares@embrapa.br parasites have a direct life cycle in a single host, which means that infection may reach high levels, and this can lead to mortality among farmed fish and significant economic losses (TOJO \& SANTAMARINA, 1998; MORALES-SERNA et al., 2018; ALVES et al., 2019). In aquaculture, diseases cause production losses of up to $50 \%$ (LIEKE et al., 2019). Therefore, problem 
prevention and use of control strategies based on globally accepted principles and locally applicable strategies are recommended (ASSEFA \& ABUNNA, 2018).

Antiparasitic drugs have been widely studied because of the need to keep farmed fish free from infection by monogeneans and therefore to support intensive fish farms. Thus, these studies have indicated that synthetic drugs should be used for controlling monogeneans using therapeutic baths (SANTAMARINA et al., 1991; BUCHMANN et al., 2011; BENAVIDES-GONZÁLEZ et al. 2014; ZHANG et al., 2014; MORALES-SERNA et al., 2018; ALVES et al., 2019).

Levamisole is one of these anthelminthic drugs. This is an anthelmintic of imidazothiazole group that immobilizes parasites by causing muscle paralysis (HARTMANN, 1989; PAHOR-FILHO et al. 2017). It has low toxicity towards fish in therapeutic baths (ALVES et al., 2019). The concentrations of levamisole used in therapeutic baths for controlling monogeneans have been ineffective (SANTAMARINA et al., 1991). Hence, this anthelmintic had not been recommended until recently, when Alves et al. (2019) reported that it showed high efficacy (88.2\%) in therapeutic baths with $125 \mathrm{mg} \mathrm{L}^{-1}$ of levamisole against Anacanthorus spatulatus Kritsky, Thatcher \& Kayton, 1979; Notozothecium janauachensis Belmont-Jégu, Domingues \& Martins, 2004 and Mymarothecium boegeri Cohen \& Kohn, 2005 and Linguadactyloides brinkmanni Thatcher \& Krytsky, 1983 in Colossoma macropomum Cuvier, 1818.

Levamisole can be delivered effectively via dietary supplementation, which would be much more feasible for industrial use, compared with injection and immersion baths (LI et al., 2006). Administration of levamisole in the dietary supplementation of fish may be an alternative for treatment against monogeneans, since this oral treatment can increase the deleterious effects on the parasites and increase the chances of fish survival (PAHOR-FILHO et al., 2017), especially when high concentrations of this anthelminthic drug are used. In addition, oral treatment eases the administration of the drug and there is no need to handle the fishes (TOJO \& SANTAMARINA, 1998). However, it has been reported that diets with high concentrations of levamisole aimed against Gyrodactylus sp. in rainbow trout Oncorhynchus mykiss Walbaum 1792 (TOJO \& SANTAMARINA, 1998) and against Heterobothrium okamotoi Okamoto, 1963 in Japanese pufferfish Takifugu rubripes Temminck \& Schlegel, 1850 were ineffective (HIRAZAWA et al., 2000). For pacu Piaractus mesopotamicus Holmberg, 1887, diets with low concentrations of levamisole did not show efficacy against Anacanthorus penilabiatus Boeger, Husak \& Martins 1995 (PAHOR-FILHO et al., 2017), or had low efficacy (SCHALCH et al., 2009). Nevertheless, dietary supplementation with levamisole has not been assayed in relation to eliminating monogeneans from $C$. macropomum. This species (popular name: tambaqui) is a serrasalmid of great importance in aquaculture in the Amazon region (ALVES et al., 2019). It is frequently infected by monogenean species (ALVES et al. 2019), which are parasites that have caused problems for fish farms from the Amazon.

Given that the effects of oral administration of levamisole have not yet been assayed for $C$. macropomum, the aim of this study was to investigate the efficacy of levamisole in the diet of this Amazonian fish.

\section{Materials and Methods}

\section{Fish and monogenean parasites}

Two hundred and fifty $C$. macropomum fingerlings $(12.1 \pm 1.1 \mathrm{~cm}$ and $40.0 \pm 11.0 \mathrm{~g}$ ) were obtained from a commercial fish farm in Macapá, state of Amapá, Brazil, and were kept at the Aquaculture and Fisheries Laboratory of Embrapa Amapá, in Macapá. The fish were acclimatized for 15 days in $500 \mathrm{~L}^{-1}$ tanks with constant water flow and aeration, and were fed twice a day with commercial feed containing 32\% crude protein, moisture (max) of $100 \mathrm{~g}$, ether extract ( $\mathrm{min}$ ) of $65 \mathrm{~g}$, crude fiber ( $\max$ ) de $70 \mathrm{~g}$ and mineral matter (max) of $140 \mathrm{~g}$ (Guabi, Brazil). The following water parameters were maintained in the tanks: temperature at $30.1 \pm 0.1{ }^{\circ} \mathrm{C}$, dissolved oxygen at $5.6 \pm 0.2 \mathrm{mg} \mathrm{L}^{-1}, \mathrm{pH}$ at $5.4 \pm 0.2$, total ammonia at $0.5 \pm 0.01 \mathrm{mg} \mathrm{L}^{-1}$, alkalinity at $10.0 \pm 0 \mathrm{mg} \mathrm{L}^{-1}$ and water hardness at $10.0 \pm 0 \mathrm{mg} \mathrm{L}^{-1}$. The organic matter that accumulated at the bottom of the tanks was removed once each two days. This stock of fish was used in the in vivo assays described below.

The monogeneans used in this experiment were obtained from naturally infested fish.

\section{Preparation of diets with levamisole and experimental design}

Levamisole (Ripercol $150 \mathrm{~F}^{\circ}$ at a concentration of $18.8 \%$ ) was diluted in distilled water and mixed into a commercial feed containing $32 \%$ crude protein (Guabi, Brazil) at four concentrations (300, 600, 900 and $1200 \mathrm{mg} \mathrm{kg}^{-1}$ of diet). A control diet $\left(0 \mathrm{mg} \mathrm{kg}^{-1}\right.$ of levamisole) was prepared using only commercial feed and distilled water. All the diets were dried at room temperature for $48 \mathrm{~h}$.

Two hundred twenty five $C$. macropomum fingerlings $(14.2 \pm 1.1 \mathrm{~cm}$ and $44.0 \pm 13.0 \mathrm{~g}$ ) were randomly distributed in $100 \mathrm{~L}$ tanks in three replicates per treatment $\left(0,300,600,900\right.$ and $1200 \mathrm{mg} \mathrm{kg}^{-1}$ of levamisole for 24, 96 and $240 \mathrm{~h}$ ). Five fish in each replicate, which yielded a total of 15 fish per treatment, were used. The fish were fed with these diets containing 0,300, 600, 900 and $1200 \mathrm{mg} \mathrm{kg}^{-1}$ of levamisole twice a day (08:00 and 16:00 h) for 24, 96 and $240 \mathrm{~h}$, to reach apparent satiation. Controls only received the commercial diet with no added anthelmintic.

The experimental tanks were maintained with continuous water flow and aeration, and the water quality parameters were monitored daily: temperature at $30.1 \pm 0.1{ }^{\circ} \mathrm{C}$, dissolved oxygen at $5.5 \pm 0.2 \mathrm{mg} \mathrm{L}^{-1}, \mathrm{pH}$ at $5.3 \pm 0.2$, total ammonia at $0.5 \pm 0.01 \mathrm{mg} \mathrm{L}^{-1}$, alkalinity at $10.0 \pm 0.01 \mathrm{mg} \mathrm{L}^{-1}$ and water hardness at $10.0 \pm 0.01 \mathrm{mg} \mathrm{L}^{-1}$. The organic matter that accumulated at the bottom of the tanks was removed once each two days.

After 24, 96 and $240 \mathrm{~h}$ of feeding with 0, 300, 600, 900 and $1200 \mathrm{mg} \mathrm{kg}^{-1}$ of levamisole, the fish were euthanized by means of medullary sectioning. Their gills were collected, fixed in 5\% formalin and examined under a stereomicroscope to identify and quantify the monogeneans. The parasites were prepared for identification as recommended by Eiras et al. (2006). After quantification of the monogeneans, the prevalence and mean abundance were calculated as described by Bush et al. (1997) and the efficacy of each treatment was estimated as proposed by Zhang et al. (2014). 
This study was approved by the Ethics Committee on Animal Use of Embrapa Amapá (Protocol № 013/2018-CEUA/CPAFAP) and was conducted in accordance with the principles of the Brazilian College of Animal Experimentation (COBEA).

\section{Statistical analyses}

The abundance data on the bath treatments were evaluated based on the Shapiro-Wilk normality test and Bartlett's test of homoscedasticity, respectively. Since the abundance data were not normally distributed, they were analyzed using the Kruskal-Wallis test for each time (24, 96 and $240 \mathrm{~h}$ ), followed by Dunn's test to comparison among medians (ZAR, 2010). The significance level was set to $5 \%(\mathrm{p}<0.05)$. Statistical tests were performed using the Bioestat ${ }^{\circ}$ oftware.

\section{Results}

None of the concentrations of levamisole (300, 600, 900 and $1200 \mathrm{mg} \mathrm{kg}^{-1}$ of diet) caused any level of mortality or behavioral alterations over $240 \mathrm{~h}$ of feeding.

After $24 \mathrm{~h}$ of feeding with 0, 300, 600, 900 and $1200 \mathrm{mg} \mathrm{kg}^{-1}$ of levamisole, the prevalence of $A$. spatulatus, $N$. janauachensis and $M$. boegeri was high. The abundance of $A$. spatulatus was similar in all treatments, while in fish fed with $300 \mathrm{~g} \mathrm{~kg}^{-1}$ of levamisole the abundance of $M$. boegeri was higher. In fish fed with $1200 \mathrm{mg} \mathrm{kg}^{-1}$ of levamisole, the abundance of $N$. janauachensis was lower than with the other treatments (Table 1 ).

After $96 \mathrm{~h}$ of feeding with 0, 300, 600, 900 and $1200 \mathrm{mg} \mathrm{kg}^{-1}$ of levamisole, the prevalence of $A$. spatulatus, $N$. janauachensis and $M$. boegeri were high and no differences in the abundance of A. spatulatus, $N$. janauachensis and $M$. boegeri among the treatments were observed (Table 1).

After $240 \mathrm{~h}$ of feeding with different concentrations of levamisole, the prevalence of $A$. spatulatus, $N$. janauachensis and $M$. boegeri remained high. The prevalence of $A$. spatulatus in fish fed with $1200 \mathrm{mg} \mathrm{kg}^{-1}$ of levamisole was low than in other treatments, as was also the abundance of $M$. boegeri in fish fed with 300 and $1200 \mathrm{mg} \mathrm{kg}^{-1}$ of levamisole (Table 1).

The efficacy of feeding with 300 and $600 \mathrm{mg} \mathrm{kg}^{-1}$ of levamisole was very low after 24,96 and $240 \mathrm{~h}$. After $96 \mathrm{~h}$ of feeding with $900 \mathrm{mg} \mathrm{kg}^{-1}$ of levamisole, the efficacy was $55.7 \%$, while after $240 \mathrm{~h}$ of feeding with $1200 \mathrm{mg} \mathrm{kg}^{-1}$ of levamisole, the efficacy was $84.6 \%$ (Figure 1 ).

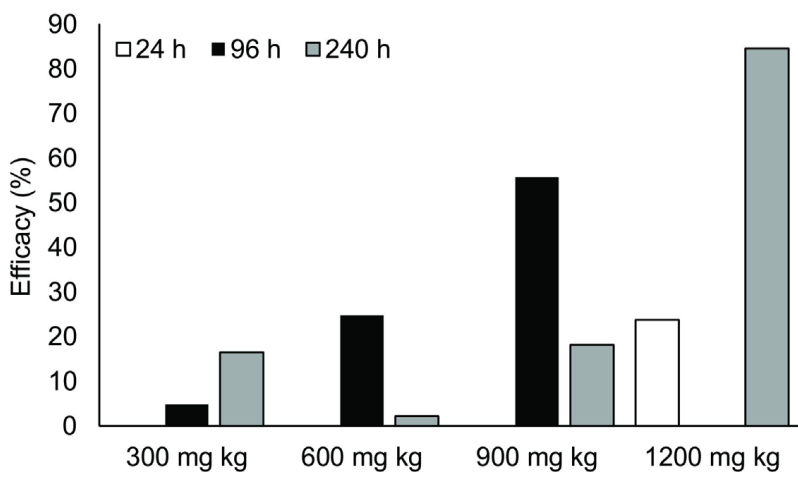

Figure 1. Efficacy of different concentrations of levamisole in the diet of Colossoma macropomum against monogeneans after 24, 96 and $240 \mathrm{~h}$.

Table 1. Prevalence (P) and mean abundance (MA) of monogeneans on the gill of Colossoma macropomum fed with different concentrations of levamisole.

\begin{tabular}{|c|c|c|c|c|c|c|}
\hline \multirow{2}{*}{$\begin{array}{c}\text { Treatments } \\
\left(\mathrm{m} \mathrm{kg}^{-1}\right)\end{array}$} & \multicolumn{2}{|c|}{ Anacanthorus spathulatus } & \multicolumn{2}{|c|}{ Mymarothecium boegeri } & \multicolumn{2}{|c|}{ Notozothecium janauachensis } \\
\hline & $\mathbf{P}(\%)$ & $\mathrm{MA} \pm \mathrm{SD}$ & $\mathbf{P}(\%)$ & $\mathrm{MA} \pm \mathrm{SD}$ & $\mathbf{P}(\%)$ & $\mathrm{MA} \pm \mathrm{SD}$ \\
\hline \multicolumn{7}{|c|}{$24 \mathrm{~h}$} \\
\hline 0 & 100 & $14.2 \pm 8.4^{a}$ & 93.3 & $4.7 \pm 4.0^{\mathrm{a}}$ & 93.3 & $10.7 \pm 9.6^{a}$ \\
\hline 300 & 100 & $11.5 \pm 5.4^{\mathrm{a}}$ & 100 & $56.6 \pm 47.8^{b}$ & 100 & $12.6 \pm 22.1^{\mathrm{a}}$ \\
\hline 600 & 100 & $18.4 \pm 14.7^{\mathrm{a}}$ & 100 & $13.8 \pm 12.2^{\mathrm{a}}$ & 93.3 & $9.9 \pm 6.3^{\mathrm{a}}$ \\
\hline 900 & 100 & $16.6 \pm 9.0^{\mathrm{a}}$ & 100 & $31.3 \pm 13.3^{\mathrm{b}}$ & 86.7 & $9.2 \pm 9.3^{\mathrm{a}}$ \\
\hline 1200 & 100 & $10.9 \pm 4.6^{\mathrm{a}}$ & 100 & $10.0 \pm 6.1^{\mathrm{a}}$ & 60.0 & $1.6 \pm 1.5^{\mathrm{b}}$ \\
\hline \multicolumn{7}{|c|}{$96 \mathrm{~h}$} \\
\hline 0 & 100 & $20.0 \pm 8.1^{\mathrm{a}}$ & 100 & $14.0 \pm 8.8^{\mathrm{a}}$ & 100 & $5.5 \pm 6.0^{\mathrm{a}}$ \\
\hline 300 & 100 & $21.8 \pm 12.1^{\mathrm{a}}$ & 100 & $12.6 \pm 11.0^{\mathrm{a}}$ & 80.0 & $3.2 \pm 3.7^{\mathrm{a}}$ \\
\hline 600 & 100 & $15.6 \pm 8.0^{\mathrm{a}}$ & 100 & $11.4 \pm 5.0^{\mathrm{a}}$ & 60.0 & $2.7 \pm 2.8^{\mathrm{a}}$ \\
\hline 900 & 90.0 & $8.2 \pm 5.2^{b}$ & 100 & $6.8 \pm 3.9^{a}$ & 80.0 & $2.5 \pm 2.1^{\mathrm{a}}$ \\
\hline 1200 & 100 & $23.4 \pm 7.2^{\mathrm{a}}$ & 100 & $13.5 \pm 5.0^{\mathrm{a}}$ & 50.0 & $3.1 \pm 3.4^{a}$ \\
\hline \multicolumn{7}{|c|}{$240 \mathrm{~h}$} \\
\hline 0 & 100 & $9.7 \pm 9.8^{a}$ & 90.0 & $7.5 \pm 4.3^{\mathrm{a}}$ & 50.0 & $1.6 \pm 1.8^{\mathrm{a}}$ \\
\hline 300 & 100 & $11.1 \pm 8.2^{\mathrm{a}}$ & 10.0 & $0.1 \pm 0.3^{b}$ & 70.0 & $4.5 \pm 4.1^{\mathrm{a}}$ \\
\hline 600 & 100 & $12.1 \pm 4.5^{\mathrm{a}}$ & 90.0 & $3.2 \pm 2.9^{\mathrm{a}}$ & 90.0 & $3.1 \pm 2.1^{\mathrm{a}}$ \\
\hline 900 & 100 & $8.4 \pm 5.1^{\mathrm{a}}$ & 70.0 & $4.4 \pm 4.4^{a}$ & 70.0 & $2.6 \pm 2.9^{\mathrm{a}}$ \\
\hline 1200 & 90.0 & $2.3 \pm 1.7^{b}$ & 10.0 & $0.1 \pm 0.3^{b}$ & 30.0 & $0.5 \pm 1.0^{\mathrm{a}}$ \\
\hline
\end{tabular}

Different letters on the same column indicate differences according to the Dunn test $(\mathrm{p}<0.05)$. 


\section{Discussion}

Aquaculture is currently a food production sector that is attracting great attention and it is growing rapidly in different countries around world (ASSEFA \& ABUNNA, 2018; ALVES et al., 2019). However, huge production losses occur within aquaculture for several reasons. Among the causes, diseases are the most serious constraint on farmers' livelihoods, through job losses, reduced incomes and food insecurity (ASSEFA \& ABUNNA, 2018). Among these diseases, those caused by monogenean parasites can become a problem under stressful conditions among farmed fish, including C. macropomum. Thus, antiparasitic treatments to control monogeneans using levamisole in the $\operatorname{diet}$ of $C$. macropomum were investigated here, since administration protocols including dosages and times had not been defined until now.

In farmed C. macropomum, monogeneans cause infections and are highly prevalent and abundant (ALVES et al., 2019). We observed high prevalence of monogeneans in $C$. macropomum in almost the treatments with levamisole, because of the monoxenous life cycle of these ectoparasites and their contact with fish in the rearing system. These factors certainly increase the ease of horizontal transmission of these parasites. Pahor-Filho et al. (2017) reported similar results for $P$. mesopotamicus infected by A. penilabiatus and fed with different concentrations of levamisole in its diet $\left(100\right.$ to $\left.500 \mathrm{mg} \mathrm{kg}^{-1}\right)$. Thus, in seeking reliable strategies for effective parasite control in C. macropomum, there is a need to determine the effects of oral administration of levamisole against monogeneans for this fish species of great importance for Amazonian fish farm.

For C. macropomum, none of the concentrations of levamisole (300, 600, 900 and $1200 \mathrm{mg} \mathrm{kg}^{-1}$ of diet) caused mortality or behavioral alterations over the course of $240 \mathrm{~h}$ of feeding. Similar results were reported for $P$. mesopotamicus fed with $100-500 \mathrm{mg}$ of levamisole per $\mathrm{kg}$ of diet, for 15 days (PAHOR-FILHO et al., 2017). The toxic effects of levamisole seem to vary with the concentration of this drug, but we no observe effect toxic of dosages used. In contrast, Li et al. (2006) observed low mortality among specimens of the hybrid fish Morone chrysops $\times$ Morone saxatilis after they were fed with 100 to $1000 \mathrm{mg}$ of levamisole per $\mathrm{kg}$ of diet for 21 days, and low doses of levamisole (100 to $250 \mathrm{mg}$ per $\mathrm{kg}$ of diet) enhanced feed efficiency. However, excessive use of levamisole in diets can cause toxicity among fish (TOJO \& SANTAMARINA, 1998; LI et al., 2006).

After $24 \mathrm{~h}$ of feeding with $1200 \mathrm{mg} \mathrm{kg}^{-1}$ of levamisole among C. macropomum, the abundance of $N$. janauachensis presented a decrease, compared with treatments with 0,300, 600 and $900 \mathrm{~m} \mathrm{~kg}^{-1}$. The abundance of $M$. boegeri also decreased after $240 \mathrm{~h}$ of feeding with $1200 \mathrm{mg} \mathrm{kg}^{-1}$ of levamisole. In contrast, in P. mesopotamicus, diets with 100 to $500 \mathrm{mg}$ of levamisole per $\mathrm{kg}$ of feed, for 15 days, had no effect on the intensity of $A$. penilabiatus (PAHOR-FILHO et al., 2017). In T. rubripes, 2 and $4 \mathrm{~g}$ of levamisole per $\mathrm{kg}$ of diet for 20 days had no effect on the abundance of H. okamotoi (HIRAZAWA et al., 2000). Tojo \& Santamarina (1998) also reported that $40 \mathrm{~g}$ of levamisole per $\mathrm{kg}$ of diet for 10 day had no effect on the abundance of Gyrodactylus sp. in O. mykiss.
Although oral treatment with levamisole concentrations higher than $40 \mathrm{~g}$ per $\mathrm{kg}$ of diet is an economically viable option, the required dosage per day will imply use of large amounts of this drug. It has been found that excessive use of levamisole in diets can cause toxicity among fish, thus resulting in reduction of growth and feed efficiency (LI et al., 2006), as well as causing liver alterations of animals (PAHOR-FILHO et al., 2017), which are all undesirable effects in fish farming. Our findings highlight the importance of instituting a sufficiently long oral treatment period and appropriate concentration, when using levamisole to reduce the load of monogeneans in C. macropomum.

For C. macropomum, $96 \mathrm{~h}$ of feeding with $900 \mathrm{mg} \mathrm{kg}^{-1}$ of levamisole had an efficacy of only $55.7 \%$, whereas $240 \mathrm{~h}$ of feeding with $1200 \mathrm{mg} \mathrm{kg}^{-1}$ had higher efficacy (84.6\%). In P. mesopotamicus, diets with 362 and $640 \mathrm{mg}$ of levamisole per $\mathrm{kg}$ feed had low efficacy (15 to $58 \%$ ) for controlling $A$. penilabiatus, and feeding for 3 days was more effective than for 15 days (SCHALCH et al., 2009). In contrast, in P. mesopotamicus, diets with 100 to $500 \mathrm{mg}$ of levamisole per $\mathrm{kg}$ feed for 15 days did not show efficacy against A. penilabiatus (PAHOR-FILHO et al., 2017). Feeding of O. mykiss with $40 \mathrm{~g}$ of levamisole per $\mathrm{kg}$ of diet for 10 days (TOJO \& SANTAMARINA, 1998) and feeding of T. rubripes with 2 and $4 \mathrm{~g}$ of levamisole per $\mathrm{kg}$ of diet for 20 days (HIRAZAWA et al., 2000) were also ineffective against monogeneans.

It seems that the liver of fish has the capacity to rapidly and extensively metabolize orally administered levamisole, such that the residues excreted into the water are very low (LI et al., 2006). Therefore, these characteristics are very suitable for use in controlling monogeneans in farmed C. macropomum. Since none of the concentrations of levamisole caused any level of mortality or behavioral alterations over $240 \mathrm{~h}$ of feeding, we recommend the controls of monogeneans using $1200 \mathrm{mg} \mathrm{kg}^{-1}$ of levamisole for 10 days. Lastly, since monogeneans elicit some of the worst problems in C. macropomum, this control method may be useful in fish farms.

\section{Acknowledgements}

The authors also thank the Conselho Nacional de Desenvolvimento Científico e Tecnológico (CNPq) for the productivity research grant awarded to M. Tavares-Dias (\# 303013/2015-0).

\section{References}

Alves CMG, Nogueira JN, Barriga IB, Santos JR, Santos GG, TavaresDias M. Albendazole, levamisole and ivermectin are effective against monogeneans of Colossoma macropomum (Pisces: serrasalmidae). J Fish Dis 2019; 42(3): 405-412. http://dx.doi.org/10.1111/jfd.12952. PMid:30659617.

Assefa A, Abunna F. Maintenance of fish health in aquaculture: review of epidemiological approaches for prevention and control of infectious disease of fish. Vet Med Int 2018; 2018: 5432497. http://dx.doi. org/10.1155/2018/5432497. PMid:29682272.

Benavides-González F, Gómez-Flores RA, Sánchez-Martínez JG, RábagoCastro JL, Montelongo-Alfaro IO. In vitro and in vivo antiparasitic efficacy of praziquantel against monogenean Ligictaluridus floridanus 
in channel catfish (Ictalurus punctatus). Wetchasan Sattawaphaet 2014; 44(4): 533-539.

Buchmann K, Kania PW, Neumann L, De’Besi G. Pseudodactylogyrosis in Anguilla anguilla (Actinopterygii: Anguilliformes: Anguillidae): change of control strategies due to occurrence of anthelmintic resistance. Acta Ichthyol Piscat 2011; 41(2): 105-108. http://dx.doi.org/10.3750/ AIP2011.41.2.05.

Bush AO, Lafferty KD, Lotz JM, Shostak AW. Parasitology meets ecology on its own terms: margolis et al. revisited. J Parasitol 1997; 83(4): 575 583. http://dx.doi.org/10.2307/3284227. PMid:9267395.

Eiras JC, Takemoto RM, Pavanelli GC. Métodos de estudos e técnicas laboratoriais em parasitologia de peixes. Maringá: Eduem; 2006.

Hartmann F. Investigations on the effectiveness of levamisol as a medication against the eel parasite Anguillicola crassus (Nematoda). Dis Aquat Organ 1989; 7: 185-190. http://dx.doi.org/10.3354/dao007185.

Hirazawa N, Ohtaka T, Hata K. Challenge trials on the anthelmintic effect of drugs and natural agents against the monogenean Heterobothrium okamotoi in the tiger puffer Takifugu rubripes. Aquaculture 2000; 188(1-2): 1-13. http://dx.doi.org/10.1016/S0044-8486(00)00334-3.

Li P, Wang X, Gatlin DM 3rd. Evaluation of levamisole as a feed additive for growth and health management of hybrid striped bass (Morone chrysops $\times$ Morone saxatilis). Aquaculture 2006; 251(2-4): 201-209. http://dx.doi. org/10.1016/j.aquaculture.2005.11.015.

Lieke T, Meinelt T, Hoseinifar SH, Pan B, Straus DL, Steinberg CEW. Sustainable aquaculture requires environmental-friendly treatment strategies for fish diseases. Rev Aquacult 2019; raq.12365. http://dx.doi. org/10.1111/raq. 12365 .
Morales-Serna FN, Chapa-López M, Martinez-Brown JM, Ibarra-Castro L, Medina-Guerrero RM, Fajer-Ávila EJ. Efficacy of praziquantel and a combination anthelmintic (Adecto ${ }^{\circ}$ ) in bath treatments against Tagia ecuadori and Neobenedenia melleni (Monogenea), parasites of bullseye puffer fish. Aquaculture 2018; 492: 361-368. http://dx.doi.org/10.1016/j. aquaculture.2018.04.043.

Pahor-Filho E, Pereira J Jr, Pilarski F, Urbinati EC. Levamisole reduces parasitic infection in juvenile pacu (Piaractus mesopotamicus). Aquaculture 2017; 470: 123-128. http://dx.doi.org/10.1016/j.aquaculture.2016.12.034.

Santamarina MT, Tojo J, Ubeira FM, Quinteiro P, Sanmartin ML. Anthelmintic treatment against Gyrodactylus sp. infecting rainbow trout Oncorhynchus mykiss. Dis Aquat Organ 1991; 10: 39-43. http://dx.doi. org/10.3354/dao010039.

Schalch SH, Moraes FR, Soares VE. Praziquantel, levamisol e diflubenzuron on controle de Dolops carvalhoi (Crustacea: Branchiura) e Anacanthorus enilabiatus (Monogenea: Dactylogyridae) em Piaractus mesopotamicus Holmberg, 1887 (Osteichthyes: Characidae). Rev Bras Parasitol Vet 2009; 18(1): 53-59. http://dx.doi.org/10.4322/rbpv.01801010. PMid:19500462.

Tojo JL, Santamarina MT. Oral pharmacological treatments for parasitic diseases of rainbow trout Oncorhynchus mykiss. II: Gyrodactylus sp. Dis Aquat Organ 1998; 33(3): 187-193. http://dx.doi.org/10.3354/ dao033187. PMid:9745715.

Zar JH. Biostatistical analysis. 5th ed. Prentice Hall: New Jersey; 2010.

Zhang XP, Li WX, Ai TS, Zou H, Wu SG, Wang GT. The efficacy of four common anthelmintic drugs and traditional Chinese medicinal plant extracts to control Dactylogyrus vastator (Monogenea). Aquaculture 2014; 420-421: 302-307. http://dx.doi.org/10.1016/j.aquaculture.2013.09.022. 